\title{
ETIENNE CABET AND THE PROBLEM OF CLASS ANTAGONISM ${ }^{1}$
}

The place of Etienne Cabet in the history of French and European socialism has been misunderstood and its real importance diminished in part due to the only detailed study of his life and thought, Jules Prudhommeaux's Icarie et son fondateur Etienne Cabet (Paris: Cornély, 1907). This work possesses many merits but is limited by the framework made explicit in its subtitle: "a contribution to the study of Experimental Socialism". The author is principally concerned with Cabet as the creator of a communist colony in the backwoods of America. This emphasis relieved Prudhommeaux of the task of investigating the role of Cabet in the turbulent politics of France before and during the Revolution of $\mathrm{I} 848 .^{2}$ By ignoring this period of Icarian history, he inadvertently strengthened the impression that Cabet's historical significance was as the Utopian archetype. ${ }^{3}$ Such was not the unique image of the father of Icarian communism during the

${ }_{2}^{2}$ The research upon which this article is based was carried out thanks to a Graduate Training Fellowship from the Social Science Research Council. I wish to acknowledge my deep appreciation to it for this opportunity.

2 Prudhommeaux legitimately justifies this lacuna in his work in the following manner: "Pour établir jusqu'à quel point l'influence du communisme icarien a été efficace et salutaire pendant les quelques années qui ont précédé la chute de la Monarchie de Juillet, il faudrait pouvoir raconter la croissance et mesurer l'extension du parti qui reconnut pour chef, dès son retour en France, l'auteur du Voyage en Icarie. La condition préalable d'un pareil travail serait une connaissance exacte des mouvements d'opinion qui, dans les différentes villes de nos provinces françaises et dans les pays voisins du nôtre, ont préparé la révolution de février 1848 . En l'état des recherches historiques, les moyens d'information nous manquent encore. Nous devons donc nous borner à quelques brèves indications qui formeront comme la transition nécessaire entre les deux parties du présent ouvrage." Icarie et son fondateur Etienne Cabet (Paris, 1907), p. I94.

3 Throughout this study, the terms Utopian and Utopian Socialist refer, for the sake of convenience, to all those whom Marx and Engels qualified as such. This does not imply that I adhere fully to their pejorative meaning of these designations. Recent works, such as Frank Manuel's on Saint-Simon and the several studies of the école phalanstérienne, have demonstrated that the oft-maligned thought of the "Utopians" contained elements of originality and sophistication not admitted by Marx as well as a great store of insights which he employed without rendering credit due. As for Cabet (who, alas, has little to recommend him on the above scores), Marx classified him among the Utopian Socialists in the Manifesto, but only on the basis of his colonial scheme (re "little Icarias"). As will be seen momentarily, the pre-emigration Cabet was not scorned by Marx and Engels. 
I 840's, however. Marx and Engels themselves were impressed by Cabet's work as a proletarian leader and classified him among the true friends of the people. ${ }^{1}$ Even after the emigration decision of May I847, which Marx censured in no uncertain terms, he continued to hold Cabet in high regard. Witness, for instance, his letter to J. B. Schweitzer of January 24, I865. In discussing Proudhon, Marx asks his correspondent to consider "the mentality of the petty bourgeois Proudhon who in an indecently brutal way - and neither acutely nor profoundly nor even correctly - attacks a man like Cabet, to be respected for his practical attitude towards the proletariat, while he flatters a man like Dunoyer (a 'State Councillor' it is true)"."2

"Cabet, to be respected for his practical attitude towards the proletariat!" Anyone reading this passing allusion of Marx whose conception of Cabet was formed by a knowledge of the Voyage en Icarie and Prudhommeaux's study would rightly be perplexed. This is because the Cabet who led the first broadly based working class political party in France to be developed in reaction to the pressures of nascent industrial growth and based on communist principles is all but unknown. This gap in the historiography of French socialism was noted almost as soon as Prudhommeaux's work was published by the able syndicalist leader, Amédée Dunois, when he wrote, in reviewing Icarie et son fondateur:

"Je suis persuadé que si Cabet n'avait fait qu'écrire son Voyage et fonder sa colonie, il ne mériterait aucunement qu'on le tirât de l'oubli. Le Cabet qui compte pour l'histoire n'est pas ce Cabetlà; c'est le Cabet des années avant 1848 , le fondateur et le chef d'un des tout premiers groupements prolétariens, d'un véritable parti ouvrier."3

Dunois went on to cite Marx's opinion in the Schweitzer letter and to urge Prudhommeaux to carry out the necessary researches to fulfill

\footnotetext{
1 'Two examples of Engels' estimate of Cabet's influence, both overdrawn, may be given. As early as November 1843, Engels said that the "great bulk of the French working classes [have] adopted the tenets propounded by M. Cabet. ..." ("Progress of Social Reform on the Continent", in: New Moral World, November 4, I843, in Marx/Engels, Gesamtausgabe, Erste Abteilung, Band 2, Berlin, 1930, p. 439.) An Engels manuscript of March I847, "Der Status Quo in Deutschland", identified Cabet as "the recognized representative of the great mass of the French proletarians ..." (Ibid., Band 6, p. 232.)

2 In the Appendix to Karl Marx, The Poverty of Philosophy (New York: International Publishers, 1963), pp. 199-200.

${ }^{3}$ L'Action directe, May 20, 1908. I am indebted to Professor Harvey Goldberg of the University of $W$ isconsin for pointing out the existence of this review. I was not aware of it until my research, begun on the basis of such an hypothesis, was well advanced.
} 
his task. Whatever his reasons, the man most learned in Icarian lore failed to write the history of Icarianism in France even though he retained a life-long interest in the problem.

In recent years, because the knowledge of the Revolution of 1848 and its background has deepened, several historians have begun to view Cabet in the fuller light implied by Dunois' critique. Pierre Angrand, Georges Duveau, and Fernand Rude have demonstrated the best understanding of the historical Cabet. ${ }^{1}$ No one, however, has made the full study of Cabet and his movement during the I 840's which is needed in order to come to a precise estimate of their historical significance. ${ }^{2}$ What is said below may be viewed as an aspect of this reassessment of Cabet. The close analysis of his changing attitude towards class relations and its tactical consequences forms an integral part of the new evaluation of Cabet so necessary for a more mature appreciation of pre-Marxian socialism (and hence of Marxism itself), of French working class development, and of the Revolution of $\mathrm{x} 848$.

Cabet is normally depicted as a Utopian who, in a fashion supposedly typical of this breed of nineteenth century social architect, failed to comprehend the real nature of social antagonism in his day and "habitually appeal[ed] to society at large, without distinction of class; nay, by preference, to the ruling class." ${ }^{3}$ This is well documented in Cabet's writings. As he wrote in the Voyage en Icarie, for instance: "But is it not especially the rich that one must convert? Without a doubt, and it would even be more useful to begin with them, because the rich and the savants have much more influence to convert the rich and the poor themselves". ${ }^{4}$ The point of this study, however, is to show that while such attitudes informed Cabet's thought when he first formulated it, his later understanding of social relations demanded that he significantly alter his position. This development occured well after Icarian communism made its initial impact on France - in the years 1845 -r 846 .

Cabet's original conception of class relations was a quite simple one. Antagonism existed to be sure, but it ranged the rich against the poor, the aristocratie against the peuple. And this antagonism could be over-

${ }^{1}$ See Angrand, Étienne Cabet et la Révolution de 1848 (Paris: P.U.F., I948); Duveau, 1848 (Paris: Gallimard, 1965), pp. 229-232; and Rude, "Introduction", to Voyage en Icarie: deux ouvriers viennois aux États-unis en 1855 (Paris: P.U.F., 1956).

2 The first, and not entirely complete attempt to deal with this problem is my doctoral dissertation for the University of Wisconsin, "Étienne Cabet and the Icarian Communist Movement in France (1839-1848)".

${ }^{3}$ Karl Marx and Friedrich Engels, Manifesto of the Communist Party, in L. Feuer, Marx and Engels: Basic Writings on Politics and Philosophy (Garden City, N.Y., 1959), p. 38.

4 Cabet, Voyage en Icarie, 3 rd ed. (Paris: Bureau du Populaire, I845), p. 564. 
come by the rational persuasion of all parties concerned that a better life could be constructed. Both terminology and general outlook unquestionably derived from Cabet's deep involvement with the history of the Great Revolution. Furthermore, he felt that the Revolution of 1830 , while it may have altered the composition of the ruling element, still left power in the hands of an aristocracy, now called the aristocratie d'argent or bourgeoise. What of the term bourgeoisie? Cabet used it to describe an element situated between the aristocracy and the people. This constituted a sensible enough estimate of the class structure of the day, for, as Adeline Daumard has shown, the classes intermédiaires comprised a definite level separate from the classes supérieures (Cabet's aristocracy of money or the grande bourgeoisie) and from the peuple in the Parisian social pyramid. In common parlance, this sizable middle class, the major elements of which were chefs d'entreprises, boutiquiers, lower echelon public functionaries, and professional men of middling income, was simply called la bourgeoisie; Daumard specifies it more carefully: its constituents were the bons bourgeois of lesser influence and the entire moyenne bourgeoisie. ${ }^{1}$ It is obvious that the term bourgeois had shed its narrow eighteenth century connotation of non-nobles who lived nobly, that is, who lived on unearned income and did not work. ${ }^{2}$ At the same time, the contemporary image of the social structure made a sharp distinction between the bourgeois aristocracy and the bourgeoisie proper. What will be relevant for this study is the fact that Cabet, who originally thought that the latter was the natural ally of the people, came to comprehend that social antagonism in the I 840's had little connection with his preconceptions founded upon the terminology of the Revolution: aristocratie was an inadequate designation for the people's enemies; the bourgeoisie figured among them as well. Furthermore, his experience as a popular leader brought him to realize vaguely that le peuple itself was perhaps a nebulous concept. Though he used this term in all his writings down to 1848 and beyond, la classe owvriere, the class of salariés impropriétaires, became the veritable class of the exploited. There remained in his writings a mixture of old and new phrases and always a confusion of economic relationships and those more properly political; hence, for instance, the repeated utilization of the word conservateurs in denouncing the exploiters of the masses.

1 A. Daumard, La Bourgeoisie parisienne de I81s à 1848 (Paris, 1963), pp. 213-217. On the bonne bourgeoisie, see pp. I72-179.

${ }^{2}$ On this question, see $M$. Vovelle and D. Roche, "Bourgeois, rentiers, propriétaires: Éléments pour la définition d'une catégorie sociale à la fin du XVIIIe siècle", in: Actes du quatre-vingt-quatrième Congrès national des Sociétés savantes (Dijon, 1959), Section d'Histoire moderne et contemporaine (Paris, 1962), pp. 483-5 I 2. 
As will be seen below, Cabet's new appraisal of the social scene motivated him to reconsider seriously his tactical position. But the latter - the pacific conversion of tous les français to the communist ideal - constituted his principal title to the distinction of chef d'école. Thus he faced a dilemma of major proportions and ended by resolving it in a fashion reminiscent of a spate of "industrial novels" then in vogue across the Channel: escape. ${ }^{1}$ Cabet's difficulties, which derived principally from his ultimately realistic evaluation of the interests of the bourgeoisie, were by no means without parallel in the other socialist schools. The most interesting was the evolution of SaintSimonian thought on the subject of class antagonism. Armand Cuvillier has already exposed this development with perfect clarity in the pages of this review. ${ }^{2}$ The final solution here, as presented by the worker editors of l'Atelier, was not escape; but, and this is of crucial importance, neither was it political in nature. Economic action carried through by the workers themselves, especially coöperation of production, was at the core of their tactical thought. Cabet, on the other hand, sought the total transformation of society by political means and ruled out the alternatives of syndicalism or coöperation; hence, the grave dimensions of his dilemma.

In analyzing Cabet's struggle with the problem of class antagonism, we make no claim that he was propounding anything original; rather the aim is to show that his approach to the social question was not so "utopian" as existing historiography would have it. His appraisal of class antagonism and related issues from 1845 to 1847 demonstrated a fairly clear, if not sophisticated, appreciation of the changing realities of the I 840 's. Moreover, it profoundly affected the whole thrust of the broad Icarian movement: blocked in his attempt to win bourgeois support for la communauté, too timid and vain to convert to a tactical approach condoning violence, Cabet suddenly announced the Icarian emigration on May 9, 1847 . There is a broader significance here, however. Given Cabet's manifold influence on the French working class, his comments on the bourgeoisie, class antagonism, and working class solidarity, especially since they came as a striking volte-face, no doubt had an impact on the mentality of the workers on the eve of the Revolution of 1848 . Of course his retention of the ideal of pacifism and the escapism engendered by the emigration plan naturally had their effect as well. The conjuncture of the two some-

1 On these, see Raymond Williams, Culture and Society (1780-1950) (New York, 1960), pp. 87 ff.

2 "Les Antagonismes de classes dans la littérature sociale française de Saint-Simon à I 848", in: International Review of Social History, I (1956), pp. 433-463. 
what contradictory positions may well have contributed to the confusion and frustration which so clearly mark working class attitudes during the revolution.

Cabet had established his reputation by 1843 as a communist who rejected the tactics universally associated with communism on the continent, i.e., the promotion of violent revolution by means of conspiratorial secret societies. He desired to bring communism out into the open. Through propaganda, the overwhelming majority of Frenchmen were to be convinced of the efficacy of his ideal society, and they would exert pressure for the reform of the suffrage; then, armed with the vote, they would democratically decide to initiate the transition to communism. This transition would be facilitated, at its inception, by a dictatorship the role of which would be to coördinate the first steps towards the new society and, if necessary, to provide leadership in the defense of the pacific revolution against foreign intervention. Unlike the Buonarrotist conception, there was no need for a long dictatorship in order to educate the nation in the virtues of communism; ${ }^{1}$ for Cabet, this education would have already taken place in the pre-"revolutionary" period. Thus Cabet's tactical program in its original form consisted of three steps: I) the development of a great cross-class movement through propaganda and organization; 2) the legal conquest of political power by the communist majority; and 3) the election (or rather acclamation) of a dictator who would initiate the transition to communism. Ideally, la communauté was to be ordained by the "general will" of the useful citizens of the entire nation. The latter included the whole of the French population except

\footnotetext{
1 Arthur Lehning, "Buonarroti's Ideas on Communism and Dictatorship", in: International Review of Social History, II (I 957), pp. 266-287. Post-revolutionary dictatorship was a constant tenet of Cabet's thought. It antedates not only his communist phase but even the publication of Buonarroti's Conspiration pour l'égalité dite Babeuf (Brussels, 1828). An unpublished manuscript in the Cabet collection at the Internationaal Instituut voor Sociale Geschiedenis (hereafter IISG), "Exposé d'une révolution nécessaire dans le gouvernement de la France" (1827) reveals that Cabet wished to install none other than the duc d'Orléans as temporary dictator after the overthrow of the Restoration. The desirability of such a dictatorship is also apparent in the Voyage en Icarie (le bon Icar) and, finally, provides the rationale for Cabet's own heavy-handed "gerance" of the Icarian colony. (The Amsterdam collection, which consists of four boxes and several folders of manuscripts, letters, and diverse printed materials collected by Cabet, was turned over to the Institute by Prudhommeaux. It and the Papiers Cabet (Série 25) at the Bibliothèque historique de la ville de Paris (hereafter BHVP) are the only collections of Cabet MSS known to me. I wish to thank Mr. B. van Tijn, former archivist for France at the Institute, for making the Archief Cabet available to me.)
} 
the "aristocrats" and their allies, the peculating and corrupt officials who filled the offices of the July Monarchy.

Thus, besides the workers, Cabet had to convince the peasantry and the bourgeoisie (as defined above) that their lives would be happier under communism. As for the former, Cabet spent little ink trying to show them the advantages of his system. ${ }^{1} \mathrm{He}$ somehow assumed that they were loyal sons of the people and, despite the fact that they constituted the largest property owning element in French society, felt that they would be impressed by the rural regime of state-owned family farms outlined in the Voyage en Icarie. Cabet proudly pointed to his little groups of faithful followers in certain villages as proof that the peasants were naturally inclined towards communism, but in fact Icarianism made no impact on rural France.

If the lack of peasant support did not overly disturb Cabet, the failure to win adherents among the bourgeoisie was a source of constant concern.

That the bourgeoisie should not be overjoyed with Cabet's Utopia is not surprising. Every bourgeois function not included under the rubric 'science' was abolished or significantly altered in Icaria. The supervision of commerce, manufacturing, and distribution of consumption goods was the responsibility of elected officials. This eliminated the whole range of bourgeois whose role in society was economic, from the pettiest shop-keeper to the great financier. Professional men (such as lawyers) and artists and intellectuals were either non-existent or so submerged by censorship as to be nothing more than entertainers or propagandists. But Cabet hoped that fear, the need for peace of mind, or pure altruism would rally the bourgeoisie to the communist banner. Playing on the first, he described for the bourgeoisie the growing desperation of the working class and the threat which the violent expression of this pent-up emotion presented to their property and their lives. The desire for peace of mind offered the positive side of the fear which should have been haunting them; the sense of guilt which possesses the bourgeois because he exploits the worker would only find relief under communism. How blissful it would be to lead a life where only love motivated human relations! The appeal to altruism meant nothing more than the demand that the bourgeoisie recognize the moral validity of communism. This was manifested in Cabet's axiom, “Communisme, c'est le Christianisme". Significantly, Cabet's most

1 Only late in 1847 did he make a concerted effort to capture peasant support. But Les Villageois (Paris, 1847), a brochure by one of Cabet's lieutenants, L. V. Maillard, was mainly for the purpose of recruiting much-needed farmers to open up the virgin land in Cabet's Texas Icaria. 
active bourgeois adherents, Charles Chameroy, a traveling salesman, and Desmoulins, a doctor at Tours, were devoted Christians.

But in order even to begin the fulfillment of his dream of a pacific communist revolution, Cabet had to win the working class. Here he achieved a high degree of success by the use of quite modern methods of mass propaganda. ${ }^{1}$ While he drew into his ranks a certain number of workers who had formerly been involved in political activity, especially in the secret societies of the later thirties and early forties, it seems reasonably clear that few of Cabet's adherents had possessed deep political convictions before coming to him. ${ }^{2}$ This points up his distinguished role in the politicization of the French working class. $\mathrm{He}$ repeatedly stressed "point d'indifférence politique!" and admonished the workers for not entering more into the political arena. ${ }^{3}$ The breadth of the Icarian following provides ample evidence of his success in developing the political consciousness of the worker. ${ }^{4}$

1 On this subject the words of Fernand Rude ought to be recorded: "Par l'importance qu'il attache à une propagande multiforme et inlassable, Cabet annonce encore notre époque où l'on standardise aussi l'opinion à coups de slogans, où l'on s'efforce de faire penser les hommes en série et où se pratique couramment ce qu'on a pu appeler 'le viol des foules par propagande politique'." Op. cit., p. 17.

2 That Cabet drew followers from among the secret societies is evidenced by several published and manuscript letters to him. His war against conspiratorial techniques was also instrumental in winning the genuine (though never complete) support of the French and German members of the Society of the Seasons and the League of the Just exiled in London during the I 840 's. See the letters exchanged between Cabet and the Sociéte démocratique française of London and the German Arbeitersbildungsverein published in the Bulletin of the International Institute of Social History, VII (1952), Pp. 87-I09 and also Max Nettlau, "Londoner deutsche kommunistische Discussionen (r845) nach dem Protokollbuch des C.A.B.V.", in: Archiv für die Geschichte des Sozialismus und der Arbeiterbewegung, $X$ (1922), pp. 362-391.

By and large, however, most of Cabet's adherents appear to be neophytes in politics. Some evidence for this is provided by the fact that the extensive list of members of the Société des Droits de l'Homme and affiliated groups appearing in the report of Girod de l'Ain, Affaire du mois d'avril (Paris, 1835) does not bear a single name of an Icarian of the $184^{\circ}$ 's known to us. A similar negative correlation obtains when one scans the list of those arrested after the uprising of June 5-6, ${ }^{8} 8_{32}$ (Archives de la Prefecture de Police, Aa/42I). Furthermore, it is quite rare for an Icarian to write of any past political involvement.

${ }^{3}$ See, for example, his comments in le Populaire, January $30, \mathrm{r} 842$.

4 No contemporary writer denies that Cabet commanded the largest working class following of any French theorist. Estimates of the number of his devotees ran as high as 200,000 . His newspaper, le Populaire, achieved a circulation of 4,500 in early 1847 and we know that he sold about 10,000 copies of his Almanach for 1845 . There were Icarians in over seventy departments of France. The greatest proportion of his followers were artisans of less than master status, and the principal centers of Icarianism were industrial cities where the modern factory system was still weak (but threatening in some cases) such as Paris, Lyon, Reims, Vienne, Toulouse, and Nantes. Occupationally, of the 462 Icarians whose professions I have identified, $43 \%$ were tailors, shoemakers, and bootmakers. Another $8 \%$ were weavers and $9 \%$ came from the building trades (including his most famous adherent, Martin Nadaud). 
Cabet felt that the only way out of the morass of capitalist society was through political action on the part of the working class and consequently took a rather dim view of purely economic measures such as mutuellisme and coöperation. ${ }^{1} \mathrm{He}$ thought that the numerous strikes of the early forties were a useless waste of the workers' blood and energy, though he appreciated how the oppressed condition of most workers in France could lead to such activity and defended them against their employers.

Almost solely on the basis of working class support, then, Cabet built his "party". Although this is not the place to present a detailed account of the development of Icarian communism, a few words about the movement are called for. When Cabet returned to France in April r 839, he was remembered simply as an important leader of the moderate republicans of the early thirties (he was secretarygeneral of the respectable Association libre pour l'Education du Peuple) whose pen was too vitriolic to circumvent the censorship - hence, his conviction for press offenses of February 28, 1834 and subsequent five year exile. In 1838 he had sent copies of the recently completed Voyage en Icarie to a select group of French socialists, including Lamennais and Voyer d'Argenson. ${ }^{2}$ A few copies of a private printing then circulated in 1839 , while 1840 witnessed the actual publication of his Utopian novel and of volumes III and IV of his Histoire populaire de la Révolution française (Paris, Pagnerre). These made his reputation as a communist. He carefully distinguished himself from "les violents" and "les matérialistes" and spoke censoriously of Babeuf's conspiracy in the Histoire populaire. ${ }^{3}$ Le Populaire began to appear in March $184 \mathrm{x}$. For two years its circulation scarcely increased, and it is clear that Cabet's major effort during this first phase of the Icarian movement was to establish a unique position for his school. He berated other socialists and even a quasi-Icarian newspaper (le Travail of Lyon) as "competitors". A constant turnover of Icarian personnel marks this phase as well. He purged the ranks of all but sheep-like followers and denounced those who defected on their

\footnotetext{
${ }^{1}$ His lead article in le Populaire, July 20, 1843 exposes his position on these questions at this point in his career. See also his brochure, L'Ouvrier; ses misères actuelles, leur cause et leur remède (Paris, June 1844), pp. I 2-13. Before his discovery of communism, Cabet took a quite different view. His Moyen d'améliorer l'état déplorable des ouvriers (Paris, 1833) advised precisely the means he later regarded as useless: through "sociétés de secours mutuels", the worker would be able to negotiate with his master "equal to equal" (p. 6). He also gave his approbation to coöperation.

2 Copies of their letters commenting on the work are preserved in the Archief Cabet, IISG: Lamennais to Cabet, Paris, April 29, 1838 and Voyer d'Argenson to Cabet, Lagrange, May 15, 1838 .

${ }^{3}$ See vol. IV, pp. 33 Iff.
} 
own account. ${ }^{1}$ The great turning point in the history of the movement came with the trial and acquittal of several of his adherents at Toulouse in September $1843 .^{2}$ From then on Icarian communism developed rapidly. By 1847 Cabet's influence in the working classes of Lyon, Vienne, Reims, Nantes, perhaps even Paris was unsurpassed. ${ }^{3}$ His "correspondants" acted as local leaders, sending reports to him, ${ }^{4}$ placing brochures, and organizing Icarian meetings, banquets, and outings. A third phase followed the emigration announcement of May 1847. Feverish preparations for the departure ensued; some Icarians defected, but many new members joined in response to Cabet's glittering promises. The Revolution of 1848 drastically undermined the colonial program and ushered in a fourth distinct phase. Cabet himself went on to play a major role during the early stages of the revolution but was destroyed by the violent anticommunist propaganda of April and May. This came about in part due to the invaluable service he rendered the beleaguered Blanqui in the wake of the publication of the Taschereau document. ${ }^{5}$ By the time of the June Days, Cabet was a broken man and his movement had lost its unity. Several shiploads of Icarians departed in order to partake of the joys of la vie commune in America during the second half of the year only to find that Icaria was a wasteland on the Red River in Texas. In December Father Cabet sailed for the New World to attempt to reconstruct the shattered Icarian dream at Nauvoo, Illinois.

As the Icarian movement evolved through its progressive phase from I 843 to 1847 , it became increasingly obvious that Cabet was facing a serious tactical dilemma. While his ranks burgeoned with workers, the bourgeoisie, whose support was of vital necessity if his revolution by the conversion of "l'opinion publique, la Reine du monde" was to succeed, demonstrated in its press an increasing hostility towards Cabet and all that he stood for. In the remaining space, I wish to set forth the thesis that this dilemma was largely responsible for Cabet's abandonment of the tactical position outlined earlier in favor of a new orientation towards escape. But escape with a purpose: in the undisturbed wilderness of America he would create not a mere ex-

${ }^{1}$ For the internal vicissitudes of the movement during this phase, see Cabet, Toute la vérité au Peuple ou Réfutation d'un pamphlet calomniateur (Paris, July 1842) and especially his Les Masques arrachés (Paris, 1844).

2 The fundamental source: Archives Nationales, BB I 8 I409 dos. 6043.

${ }^{3}$ See my Ph. D. dissertation, op. cit., Part II, Chapter 4.

4 Several of these may be found among the Papiers Cabet, BHVP.

${ }^{5}$ On his noble and selfless assistance to Blanqui, see M. Dommanget, Blanqui calomnié; une drame politique de 1848 (Paris, 1948), pp. $83 \mathrm{ff}$. 
perimental colony, but a great communist nation, a monument to set before a world of unbelievers. Such was the new Icarian "tactic". Since this redirection of Icarianism is the aspect of Cabet's activity which brought on his condemnation by left-wing militants in his own day and the ridicule of many later historians, it is worthwhile to probe its foundations. It will be seen that before he reached the electrifying but totally naïve decision to "go to Icaria", Cabet found himself confronted which another conclusion which, had he fully articulated it, would have been equally electrifying an infinitely more realistic in light of conditions at this point in French social history: that the recognition of the abyss separating the bourgeoisie from the working class pointed to the necessity of embracing violent proletarian revolution. But Cabet was the master of a movement the uniqueness of which derived largely from its strong stand in favor of class collaboration and against revolutionary violence. Besides that, he looked upon himself as a bourgeois whose vocation was that of a professional theorist. By declaring war on the bourgeoisie Cabet would have undermined the singularity of his communism and would have had to relinquish his cherished image as the bonbomme who grandly linked bourgeoisie and proletariat. This study has two interrelated aims, therefore: 1 ) to prove that Étienne Cabet, the most Utopian of Utopians in historiographical opinion, in fact came to comprehend the problem of class antagonism, and that on the basis of this perception, he began to promote the doctrine of working class solidarity as well as the idea that communism could only be a working class ideology; but 2) when faced with the tactical program logically derivative from this comprehension - the affirmation of class warfare, of proletarian revolution - he shrank away, finally choosing to escape. Allons en Icarie! is the desperate cry of a man whose dream of convincing naturally good and rational mankind of the joys of life en communauté is destroyed by the hard facts of social reality.

\section{II}

In the first place, the foregoing hypothesis would have no validity if it could be shown, as Georges Sencier thought probable, ${ }^{1}$ that Cabet intended all along to become an experimental socialist. To begin with, it should be noted that this designation is not even completely correct when one assesses Cabet's objectives as stated in May 1 847. Icaria was not to be a small scale experiment on the order of Owen's communities, the phalanstères, or Minter Morgan's Christian Commonwealth. Rather,

1 Sencier, Le Babouvisme après Babeuf (Paris: Rivière, 1912), p. 196. 
it was to include, from the very beginning, some 20,000 Icarians and would quickly become a veritable communist nation. It was to be an "émigration", not merely a little band to try out a new form of social organization in the wilderness. ${ }^{1}$ That it became such was the result of four circumstances: Icarian refusal to participate, the inability of many who wished to go to make the necessary contribution for admission, above all, the Revolution on $\mathrm{I} 848$, and finally, the failure to procure a decent location to set up the new society.

It must be admitted that through the period from the founding of le Populaire to the decision to emigrate, Cabet did on occasion mention the possibility of creating some sort of communist experiment; but there was never a question of leaving France, for the Icarian leader was wary of such adventures in light of the repeated Owenite and Fourierist failures. It is evident, in general, that the question of attempting an "expérience" was of minor importance for Cabet. The following summary of Cabet's ideas with regard to the tactic of experimentation and/or emigration should show the very ambiguous and incidental role which this kind of thinking played in his writings before May 1847 . This survey will point up why the call to emigrate came as such a thunderbolt when it was made.

Cabet was aware of the possibilities and limitations presented by the creation of experimental communities even at the time of his conversion to communism during his London exile. It can now be definitely proved that he was in personal contact with Owen at the time. ${ }^{2}$ In speaking of the founder of New Harmony in the Voyage en Icarie, Cabet praised his thought and his generous soul but felt that he had wasted precious funds which could have been used for propaganda purposes on his "essais de Communautés partielles et trop petites". ${ }^{3}$

In the second issue of le Populaire, Cabet made himself more explicit: "Il y a plus: nous pensons que la Communauté est d'autant plus facile que le pays est plus grand, le Peuple plus nombreux, l'industrie plus puissante; nous pensons qu'un essai fait en petit n'aurait pas de chances de succès, et que le mauvais résultat d'une pareille expérience ne pourrait rien prouver contre un essai fait en grand."4 In

${ }^{1}$ Le Populaire, May 9, 1847.

2 The Owen Papers at the Coöperative Union library in Manchester (on microfilm at the University of Wisconsin) contain a letter from Cabet to Owen (August I 5,1847 ) demonstrating this relationship: "Vous n'avez pas perdu, j'aime à le penser, le souvenir de nos fréquentes entrevues soit chez vous, soit chez moi ..., pendant mon exil politique en Angleterre." Letter no. I ऽ03, U.W. film no. I090.

3 Cabet, Voyage en Icarie, p. 519.

4 Le Populaire, April 18, 184 r. 
July 1842 , Cabet cautioned against emigration of any kind saying that "les Européens ne peuvent prendre trop de précautions et trop de garanties avant de quitter leur patrie pour se transporter sur une terre lointaine, inconnue et toute différente", and two months later he enunciated his fundamental objection to socialist experiments overseas (this in reference to a report on the Fourierist Brazilian colony): "Et ce qui nous paraît le plus certain dans les émigrations, c'est qu' elles privent la cause populaire d'un grand nombre de défenseurs dont le dévouement lui aurait été plus utile au milieu des crises qui s'approchent."1 These, of course, are precisely the admonitions which would be aimed at Cabet himself after May I 847. That the foregoing arguments were reiterated in the Almanach for 1843 demonstrates the strength of Cabet's convictions. ${ }^{2}$

At about the same time, however, Cabet considered two alternatives for the creation of an "essai pratique". On one hand, he vaguely suggests the possibility of using governmental resources and convicted criminals "à transformer un département en Communauté, ou à essayer une grande Communauté dans une colonie!"3 Two points must be made here. This single sentence is a part of an article on prison conditions, and Cabet does not embellish the idea in any way. Furthermore, he is suggesting public initiative in carrying out the program. Aside from this rather special proposal, however, nothing indicates that he had abandoned his general opposition to emigration and overseas experimental communities. This is evident in the issues of $l e$ Populaire of February 10, April 9, and June 10, 1843 . In the last, he denounces the Fourierist promoters of the disasterous scheme to create a phalanstère in Columbia in these terms: "Voilà le pays, où les malheureux sont allés s'établir [this follows a description of the Columbian climate and terrain], sans le connaitre et sans informations sufficientes, refusant d'écouter toutes les observations contraires! Et pour combler le malheur, la division éclate parmi eux, en sorte que ces émigrants n'aspirent plus qu'à revenir dans leur patrie!" :4

Secondly, in I 843 Cabet began to think about the only serious proposal for an experimental community he ever made. It was set down in print in the Almanach for I 844 under the name Petite Com-

${ }^{1}$ Le Populaire, July 3, I 842 and September ir, I842.

2 Almanach icarien astronomique, scientifique, pratique, industriel, statistique et social pour I 843 (Paris, December I842), pp. 95-96. The series of almanachs published by Cabet during the forties, little exploited by historians, contains valuable information on the Icarian movement.

3 Le Populaire, November $13,1842$.

4 Le Populaire, June 10, 1843 . One wonders if Cabet recalled these words as reports arrived about the collapse of his Texas colony during the summer of $184^{8}$. 
munauté des dévoués. Another version of this article appeared in le Populaire on May 2, 1844. The nature of the organization can best be described as a laboratory of communism. A small core of men (no more than twenty) should associate themselves to form a "single soul" devoted to the principle of "Christian fraternity". Around this core would be two groups - pensionnaires payants and pensionnaires ouvriers who would stay for three months in order to practice various aspects of communitarian life and to drink deeply of Icarian doctrine. The dévoués would consist of eight to ten writers, five to six workers, and five to seven "others" (rich and generous donators). Cabet was purposely vague on the precise organization of the community because the major aim is to try diverse methods, to study the results of each, and to publish the findings. ${ }^{1}$ The community, to be located in Paris or nearby, would also serve to propagandize the Icarian cause: "Tous leurs écrits et tous leurs actes exciteront toutes les classes à la bienveillance réciproque, à l'union, à la concorde, à la pratique du vrai Christianisme et de la fraternité." 2 The community was therefore conceived to be a part of his overall program of propaganda and was certainly not considered the first in a series of localized communitarian cells which would multiply and eventually engulf France; unlike Fourier or Raspail, Cabet was totally opposed to such decentralization: the nation was his societal unit.

The last mention of this scheme came on July 12 , 1844 . In this number of le Populaire, he printed a letter from the Société démocratique française of London questioning the efficacy of any such enterprise. He remarked that their apprehension was well founded given the numerous failures of such undertakings but still indicated that he was not yet ready to give up the idea. ${ }^{3}$ Never-the-less, his later silence on the issue shows that, in reality, he may have been convinced by their arguments.

Cabet made two other statements on the question of communautés partielles after July I 844. In the heat of a controversy with the Fourierist journal, la Démocratie pacifique, he reacts to their charge that he is afraid to test his system with an experiment by saying that he has not yet had the opportunity and therefore advises them not to decide that the realization of communism will lead only to "disorganization and anarchy" before "an experiment on our part". "This isolated

${ }^{2}$ Cabet presents this point of view with especial clarity in a letter (July 3, 1844) answering the objections made by the Société démocratique française of London in their meetings of May 6 and May 13, 1844. Archief Cabet, IISG.

${ }^{2}$ Le Populaire, May 2, 1844.

${ }^{3}$ Le Populaire, July I 2, 1844 . The original may be found in the Archief Cabet, IISG.

4 Ibid., August 16, 1845. 
comment is the most outspoken avowal of an intention to create an experimental community to appear in Cabet's writings before May 1847. The circumstances reduce its importance, however. At this point Cabet was locked in a furious duel of words with the chief organ of Fourierism. The absence of any positive follow-up to the remark provides evidence that it was more a technique of argumentation than a statement of intent. Furthermore, it is contradicted by his comments of September 27, 1846. He points out that experience demonstrates the futility of attempts to construct "communautés partielles" and reiterates the necessity of propaganda in order "to multiply the number of men capable of the common life". ${ }^{1}$

Although all of this indicates that Cabet's attitude towards experimentation was neither concise nor completely consistent, the weight of the evidence points to the conclusion that before the revelation of his "grande confidence" of May 9, 1847, he was opposed to emigration and wary of communitarian experiments. This should hardly be surprising since the whole thrust of his program was conceived in a Jacobin framework. A highly centralized communaute of the entire French nation was the Icaria of Cabet's dreams. Moreover, the citations made above comprise nearly the entire body of his comments on experimentation and emigration. That they are so few in number provides further proof of Cabet's disinterest in such questions before I 847 .

But suddenly and dramatically, Cabet called upon his charges to abandon France and the struggle in Europe and to follow him to a distant and unknown place in order to "realize" Icarian communism. ${ }^{2}$ Let us now attempt to demonstrate the validity of the hypothesis presented earlier: that this decision followed from Cabet's realization that existing class antagonism destroyed the viability of his previous conviction that the bourgeoisie would come to communism; it allowed him to sidestep the conclusion towards which his trend of thought was leading, that is, towards the affirmation of working class revolution against the propertied interests.

\section{III}

To understand this development, the first task is to isolate the major issues upon which his tactical dilemma turned. Four interrelated

1 Ibid., September 27, 1846 .

2 Support for the assertion of the suddenness of this decision may be found in P. Angrand, op. cit., pp. 27-28. When did Cabet make up his mind to go? A letter from his closest contact in London, Camille Berrier-Fontaine helps answer this question. On April I3, 1847, he advised Cabet: "Ne pensez point à coloniser." This is in response to a letter from Cabet of early March (since lost to us) posing this possibility. Papiers Cabet, BHVP. 
phenomena were involved: 1 ) Cabet's changing attitude towards the bourgeoisie and the possibility of class collaboration; 2) his enunciation of the principles of working class solidarity and exclusivism; 3) his proposition that capitalist concentration actually paved the way for the socialization of the means of production; and 4) his concept of revolution.

The first two are so closely interconnected that it is better to deal with them simultaneously. As Cabet dispairs of bourgeois collaboration, he increasingly invokes working class solidarity and condones exclusivism.

In Cabet's writings of I 84I-I843, his well known position in favor of class collaboration and his trust that the bourgeoisie would rationally comprehend the necessity of communism were fully and repeatedly expressed. In Ma Ligne droite (September 184I), he aired his belief that "s'il est vrai que la Bourgeoisie ne peut rien sans l'appui du Peuple, il est également vrai que le Peuple ne peut rien sans le secours de la Bourgeoisie." $\mathrm{He}$ goes on to counsel the workers to rely on "courage civil" and to work for the legal establishment of communism. The major propaganda device is the incessant preaching of the brotherhood of all men. Cabet repeated the same themes in his diatribe against the editors of l'Atelier but struck out specifically against working class exclusivism. "Oui, que le prolétaire ne se fasse pas de fatales illusions, le Peuple n'a fait aucune conquête sans le concours d'une partie de la Bourgeoisie; il ne peut rien sans elle, ne fera rien sans elle; et rien n'est plus anti-populaire que la séparation et l'exclusion entre les travailleurs et les bourgeois qui, de cœur et d'âme, sont dévoués à leur cause."2 Of course he also spoke to the bourgeoisie. The following provides an excellent example of Cabet's typical ploy of threatening it and appealing to its finer instincts at the same time.

"Ne fermez pas les yeux sur la diminution croissante du salaire de l'ouvrier, sur son manque de travail, sur la rareté et la cherté des aliments du pauvre, sur l'augmentation des impôts, sur la misère, sur le désespoir concentré dont l'explosion peut n'en être que plus terrible! Respectez la dignité d'homme dans ces prolétaires qui, aux yeux de la philosophie comme à ceux de la religion, sont réellement vos frères! Soyez compâtissants, humains, justes envers ces travailleurs dont les bras vous nourrissent, vous vêtissent, vous logent, dont un grand nombre méritent votre estime par leurs vertus, et qui tous méritent votre bien-

${ }_{1}$ Ma Ligne droite ou le vrai chemin du salut pour le Peuple (Paris, 184I), p. 37.

${ }^{2}$ Cabets, Réfutation des doctrines de l'Atelier (Paris, March 1842), pp. IO-I I. 
veillance et vos égards parce qu'ils tous sont les victimes d'une tyrannique organisation sociale qui leur refuse l'éducation et l'instruction sans même leur assurer du travail et du pain! Soyez justes par amour de la justice et de l'humanité! Soyez-le du moins par prudence et par intérêt bien entendu! Car ce serait folie d'oublier que 'ventre affamé n'a pas d'oreilles' et que 'personne n'écoute moins la raison que le désespoir!'"1

Numerous other examples of these sorts of appeals could be presented because they represent the "orthodox" Cabet. Nor can there be any doubt about the sincerity of this position. Cabet disavowed followers who were not willing to support his views in favor of class collaboration. For example, the central question at stake in a letter of August I 842 from five Lyonnais adherents is their interest in working class solidarity and their strong belief that the worker must solve his own problems: how can one contemplate an alliance with people "who consider this exploitation [of worker by employer] to be a right . . .?"2 Cabet took umbrage at this in a brochure in October 1842 and wrote them out of the Icarian camp. ${ }^{3}$

As late as February I 845 , Cabet was still intent upon making the bourgeoisie see the error of its way; at that time he published the brochure of "un prolétaire"4 called L'Esclavage du riche, in which the author tries to demonstrate that the bourgeois is enchained by his property and haunted by the fear of losing it to such an extent that his misery is equal to that of the worker whom he oppresses. Furthermore, he finds it inconceivable that the rich can actually prefer a "life of hate" to a live of love and faternity. ${ }^{5}$ Cabet thought this work "remarkable" in all respects and obviously retained faith in the future approbation of communism by the bourgeoisie. The following May, Cabet, clearly frustrated by his failure to achieve this goal, issued the grave warning that a "storm" was brewing throughout Europe, not only because of political tyranny but also and especially due to

\footnotetext{
1 Cabet, Toute la vérité au Peuple ou réfutation d'un pamphlet calomniateur (Paris, July I842), p. III.

2 G. Vincent, Grinard, Greppo, Perret, and Calandras to Cabet (undated, but internal evidence establishes that it was written in August r 842), Papiers Cabet, BHVP. All these men were significant figures in the working class movement of Lyon; Greppo, the best known, will be elected to the Constituant Assembly in $x 848$.

3 Cabet, Utile et franche explication avec les communistes lyonnais sur des questions pratiques (Paris, I842). See especially pp. I $\mathrm{ff}$.

4 This was none other than Aloysius Huber (or Hubert), who was to proclaim the dissolution of the Assembly on May I5, 1848.

5 L'Esclavage du riche (Paris, 1845), p. 14.
} 
"les vices de l'organisation sociale, l'égoïsme ou l'individualisme qui lui sert de base, la concurrence, le développement universel des machines et de l'industrie joint à une inique distribution de la richesse publique, la diminution du travail et du salaire, l'accroissement de la misère, le désespoir des masses, la résistance des conservateurs et les Bastilles."1

The only means to avoid this imminent cataclysm is through "the union of minds and in the unity of efforts" among all democratic reformers, bourgeois and proletarian alike. But he is no longer sure that time remains, for the specter of social war hangs heavy over Europe. Still he counsels that all communist workers must continue "to extend a fraternal hand to all sincere Democrats". ${ }^{2}$ This, in a sense, may be seen as a final stand by Cabet to promote bourgeois-working class collaboration in the fight against the vicious organization of their society. Later that year he was to begin to forsake his long-held hope that at least the most "advanced" segment of the bourgeoisie would come to his point of view.

From September 1845 to December 1846 , it is possible to trace a development in Cabet's thought in which he recognizes the hostility of the bourgeoisie towards working class interests and enunciates the idea that its only reason for supporting democracy is so that it may use the workers, as it did in 1789 and 1830 , to promote its own designs; at the same time, he increasingly stresses the need for working class solidarity in view of the apparent fact that union with the bourgeoisie is impossible. The crisis which brought on the new position was the outright rejection of Cabet's advances by Ledru-Rollin and la Réforme.

Le Populaire and la Réforme had, in the past, been on fairly amicable terms, even to the point of working together on certain schemes. The most important of these was the great petition promoted by la Réforme in 1 844; many Icarians helped to gather signatures. Moreover, in at least one city, Rouen, there actually existed "an association" which solicited subscriptions and shares for the two newspapers simultaneously. ${ }^{3}$ In Les Masques arrachés (1844), when he was not slandering his former associates, ${ }^{4}$ Cabet made every effort to curry

1 Cabet, Le Cataclysme social ou conjurons la tempête (Paris, May I 845), pp. 3-4.

2 Ibid., p. 2 I.

3 Procureur général de Rouen to the Garde des Sceaux, April 23, 1844, Archives Nationales, BBI8 I42I.

4 This brochure is one of the most vicious pieces of political journalism to be published in the $184^{\circ}$ 's. As noted above, before the Toulouse triumph of September 1843, the Icarian party was rent by internal conflicts, most of which revolved around Cabet's 
favor with the bourgeois radical left, especially with Ledru-Rollin. But he received a rude shock in September 1845 when, in a speech at Le Mans, Ledru-Rollin specifically and vehemently rejected communism and quoted Robespierre in his support.

Cabet discussed this turn of events at length in the September ig issue of le Populaire. Besides presenting Buonarrotist arguments that Robespierre was a harbinger of communism, he stressed that LedruRollin's denunciation of the communists was a shattering blow to the movement of democracy; in so doing, it was alleged, he was cutting himself off from a large segment of the working class. On the final page of this issue of his paper, Cabet then called on all communists to redouble their efforts and to gird themselves for the prospect of operating in a sphere separate from the types represented by la $R \dot{e}-$ forme; if they are abandoned, so be it - they will have to go on alone. ${ }^{1}$ The following month Cabet raised the question of la Reforme again and pointedly labeled it "an organ of the bourgeoisie". This was fully intended as a denigration because in the same breath he reminded his readers of the betrayal of the "proletarians" by the bourgeoisie in the Revolutions of 1789 and 1830 . In essence, la Réforme had sold out to the propertied interests. ${ }^{2}$ The split between Cabet and la Réforme evoked comment from a man who identified himself only as "un détenu politique" in a letter written on November I0, I845. An old warrior of democracy from the struggles of the thirties, he felt that the foundations of the rift were shallow. Right-thinking men of the bourgeoisie should not be inimical towards communism, nor should Cabet be disturbed by the revolutionary tone of la Reforme in light of his own revolutionism of the early thirties. ${ }^{3}$ Cabet's reaction to this letter would be most revealing, but infortunately we have no knowledge of it. At that very moment, however, he was preparing a tract which was to show that he had moved to a new level in his attitude towards the bourgeoisie. In Salut par l'union ou ruine par la division, la paix ou la guerre entre le Populaire et la Réforme (November 1845), Cabet still entertained the hope that la Réforme would come to appreciate communism but made it clear that he was unwilling to compromise any of his principles by moving toward it. There is no middle ground between "individualism and communism", and la Réforme appears to have opted for the former. With this development, the last hope of bourgeois support for communism seems to have disappeared. He

dictatorial attitudes. In this pamphlet he "unmasked" many of his former adherents, often in sordid detail.

1 Le Populaire, September 19, 1845.

2 Ibid., October I 8, I 845.

3 Papiers Cabet, BHVP. 
closed with a section entitled "Attitude du Peuple envers la Bourgeoisie". He began by saying that it seems that most bourgeois refuse their extended hand; then, like the older Cabet: nevertheless, make them "l'offre de l'alliance fraternelle". But in his following words, his new position became clear:

"Mais soyons fermes! si la Bourgeoisie s'obstine à nous repousser, il faut bien nous résigner à être repoussés. Alors, serrons nos rangs; marchons séparément de notre coté. Seulement, au lieu de faire l'avant-garde, comme autrefois, formons l'arrière-garde et l'armée de réserve; laissons la Bourgeoisie s'engager, et ne nous lançons nous-mêmes que pour décider et diriger la victoire à notre profit comme au sien."1

The last three words, of course, undermine any thesis which would maintain that Cabet had adopted a position which fully embraced class antagonism and the necessity of the destruction of the bourgeoisie as a class. But this statement was a patent warning to the workers that they could not trust the bourgeoisie. Furthermore, it had revolutionary overtones and provided advice to the workers on their role in a revolutionary situation; he reiterated in the following paragraph: "... plus de duperie, et ne nous brûlons plus les doigts pour tirer du feu les marrons qu'elle [the bourgeoisie] mangerait sans nous en laisser!" Finally,

"Nous avons toujours dit que le Peuple ne pouvait rien sans la Bourgeoisie, et c'est vrai dans l'état actuel. Ce principe, d'ailleurs, est éminemment utile pour nous préserver d'une confiance aveugle qui pourrait nous être funeste: mais il est bien plus vrai encore que la Bourgeoisie, qui n'est qu'un privilège et une espèce de caste, peut disparaître et disparaîtra devant le principe de l'égalité et de la fraternité, tandis que le Peuple ne peut pas périr."2

This blatant assertion that it will disappear was Cabet's most direct disavowal of the bourgeoisie in the corpus of his writings to this point; note however, that in his rhetoric, this disappearance will be brought about by the establishment of a principle. We shall see shortly that Cabet also perceived concrete developments in the capitalist system which would have the same effect. The foregoing is a significant statement also because in terming it "a privilege and kind of

Cabet, Salut ou Ruine, p. so.

2 Ibid. 
caste" Cabet seems to be reclassifying the bourgeoisie, removing it from among the useful elements in society.

The polemic with la Reforme thus emerges as the crucial turning point in Cabet's attitude towards the bourgeoisie. It developed in September, October and November 1845. The September 19 issue on the situation evoked reactions among Icarian sympathizers. A letter from Chaville (Charles Chameroy), Cabet's traveling representative, pointed out that the split was causing "réformistes" to cancel their subscriptions to le Populaire, but "your true friends will not abandon you". ${ }^{1}$ The latter is shown by a series of letters which Cabet printed in the issue of November 22, 1845. One was sent by "five exmembers of the comité réformiste" who quoted Robespierre's famous dictum that existence is the first of human rights. They have rallied to Cabet because communism is the logical conclusion from this position of "this incorruptible friend of the people". Eleven workers from Nantes were convinced that "Ledru-Rollin has sold out to the bourgeoisie". Seventy-two Vienne workers were astounded that LedruRollin could say what he did in light of the fact that "Christ was a communist". But twenty proletarians who labored together in a Parisian workshop squarely faced the central issue:

"Les communistes ne veulent pas détruire, ils veulent rétablir la Société sur les véritables bases; ils ne séparent pas leur cause de celle du Peuple; la fraternité universelle est leur but; ils sont pacifiques, et ont conscience de leur force; ils sauront s'en servir lorsqu'il en sera temps; mais des mots ne sauraient les satisfaire; le beau langage d'un homme a pour eux peu de valeur; ils ne considèrent que ses actes, si par la pensée ils séparaient la Société en deux camps, s'il y avait lutte, la victoire ne serait pas douteuse: la bourgeoisie, égoïste, habile par la ruse au trafique, fainéante quant à la production de la richesse qu'elle amasse, n'essaierait pas de lutter contre les bras nerveux des producteurs; et ceux-ci, quoique moins polis que ceux-là, ont des qualités que les autres n'ont pas; ils ont cœur pour aimer et un sentiment pour compâtir, non par de stériles grimaces, mais par des actions au soulagement de leurs frères malheureux, en prenant sur le nécessaire l'obole qui contribue à marquer les récompenses des grandes actions de l'homme ....".

They asserted further that "the workers are communists". Thus,

${ }^{1}$ Le Populaire, October $18,1845$.

2 Ibid., November 22, 1845 . 
according to them, the communist working class has consciousness of its own power and could sweep the unproductive bourgeoisie, whose only source of power is its cleverness, aside with a flick of its collective finger. Though they do not outwardly posit class war, they present the image of the sleeping giant whose force cannot be disregarded. A letter from Périgueux bearing twenty-one signatures specifically identified le Populaire as the organ to cement working class solidarity - the emphasis on exclusion is obvious: "Nous disons, en terminant, à tous nos frères: Regardons-nous tous comme solidaires: serrons-nous encore et rallions-nous auprès de notre Populaire; qu'il devienne désormais le centre commun où doivent se réunir tous les Travailleurs; il est notre guide et notre défenseur!' 1

"Henceforth": here is the key to the new atmosphere which was being generated within the Icarian movement. The break with la Reforme was seen as a turning point; bourgeois collaboration no longer seemed visible on the horizon; communism could only be a working class movement. On November 16, 1845 a meeting of the Assemblee générale des actionnaires du Populaire met in Paris in an air of "unanimity and enthusiasm". The decision was made to promote the "closing of ranks" and to emphasize general working class solidarity based on communist principles. Cabet stated that the "haute portée des décisions prises, ouvrent une Ere nouvelle dans l'histoire du communisme."2

Throughout the following year Cabet increasingly emphasized the need for working class solidarity and warned the workers that to trust the bourgeoisie was sheer folly. The latter point included the repeated recollection of the fruits of the révolution escamotée of 1830 : while workers die from lack of work and bread, "the loups-cerviers easily make millions at the Bourse." 3 Furthermore, he issued the warning that any revolution in the near future would again be swallowed up by bourgeois who in this instance would call themselves democrats. Here Cabet spoke as a Cassandra. This was one of his main reasons for retaining his fear of and opposition to revolution. The major aspect of the new outlook, however, was the promotion of working class solidarity. Concommitant with this was the redirection of Icarian propaganda. The bourgeoisie was villified and little attempt was made to gain even the adherence of the bourgeois democrats.

A few citations suffice to indicate Cabet's new anti-bourgeois and working class solidarist position. In December 1845 he printed an

1 Ibid.

2 Ibid.

Ibid. 
article by Julien Chambry, his correspondent at Mirecourt. He works from the premise that the working class is exploited by its masters:

"Prolétaires, notre existence est un tissu de misère et d'esclavage; un grand nombre d'entre nous naissent et meurent dans l'indigence; dès l'âge le plus tendre nous sommes exploités; parfois la proie d'hommes cupides et inhumains qui s'engraîssent de notre sueur, non contents de s'enrichir à notre détriment, nous dédaignent et nous outragent!!!" 1

The only alternative to this "system of the exploitation of man by man" is communism to which he calls the "proletarians" (specifically) to rally. No appeal whatsoever is made to the exploiters to mend their ways.

Le Populaire of April 25, 1846 took up the grave issue of the miners' revolt against the oppressive cartel among the owners in the SaintEtienne coal basin in which several workers were killed by royal troops. Though saddened by the violence of the workers, Cabet viewed the uprising as the natural outgrowth of the intolerable exploitation, bordering on slavery, to which the owners submitted their men. He understands the conditions existing there:

"Mais les nombreuses compagnies qui exploitent les mines de houille se réunissent, s'associent, ou se coalisent et se concentrent, achètent même le chemin de fer et le canal, pour ne plus se nuire par la concurrence, pour accaparer et monopoliser, pour dicter la loi à tout le monde, pour diminuer le salaire des ouvriers, pour augmenter le prix de la houille, pour s'enrichir aux dépenses des travailleurs, de l'industrie et du public: Quel cancre est l'égoïsme ou cupidité."

Such is the power of the bourgeoisie when in coalition. A month later, Cabet presented the antidote to this evil kind of bourgeois solidarity. No longer can we expect "pleas to the rich" to accomplish anything: only in the spirit of "fraternity and solidarity" among the workers themselves will the road be opened to the new organization of society. ${ }^{2}$

${ }^{1}$ Almanach icarien pour 1846 , pp. I 79 -I 80 .

${ }^{2}$ Le Populaire, April, 1846 and May 29, 1846 . Cabet's discussion of the émeute in the Saint-Etienne basin seems to have had some effect. In October 1846, Piou, the procureur général of Lyon, informed the Minister of Justice of "the invasion of communism into the coal basin"; the propagandists had come from Lyon (Archives Nationales, BBr 8 I441). It is not clear if this was Icarian activity, but letters to le Populaire from Saint-Etienne and Rive-de-Gier early in 1848 indicate Icariain nfluence there. 
The idea expressed in the word "solidarity" was a relatively new one in 1846. Flora Tristan popularized it in her great and passionate work, Union ouvrière (Paris, I 843). Cabet had originally rejected her entreaties for assistance in its publication (it was "unnecessary competition" to his own efforts) and disclaimed the idea of exclusive solidarity among workers as late as June $1845 .{ }^{1}$ But he had already faced the force of the influence of her ideas; late in 1844 , it was clear that her doctrine was making headway in Lyon, possibly at the expense of his own. ${ }^{2}$ After the la Réforme affair, union ouvrière and solidarity became repeated themes in Cabet's writings. In his lead article of June 27,1846 we find him saying to the workers:

"Comprenez-vous que votre union fera votre force, que votre isolement perpétuerait votre faiblesse et votre impuissance, qu'il faut aimer pour être aimé, secourir pour être secouru? Comprenez-vous que la pratique de la Fraternité fera votre bonheur et que, si vous adoptez universellement cette Doctrine, vous assurerez à jamais une félicité toujours croissante pour vous, pour vos enfants, pour les Générations futures, pour l'Humanité toute entière."3

The most forceful statement Cabet made on this issue appeared in the Almanach for 1847 . He was discussing the Compagnonnage and despaired of the hatred which existed among its different branches; he also condemned the lack of sympathy between workers in different cities. Given a continuation of this, "les Travailleurs seront toujours persécutés, opprimés, malheureux".

"La misère ne cessera pour eux que quand l'esprit de fraternité et de solidarité sera universel, quand [...] tous les ouvriers d'un département, tous les ouvriers de France, même tous ceux d'Europe, comprendront bien qu'ils sont frères, qu'ils ont un intérêt commun, qu'ils doivent se secourir et signer tous une pétition pour réclamer la justice et leurs droits.

Tous les ouvriers ont, en général, de bonnes intentions, de bons sentiments, et feraient le bien s'ils le connaissaient. Malheureusement, jusqu'à présent, on les a trompés et égarés en jetant parmi eux des préjugés, des préventions, des superstitions, qui les divisent sous prétexte de les unir, et qui leur sont funestes au lieu de leur être utiles."4

1 Le Populaire, June 13,1845 .

2 Archives Nationales, $\mathrm{BB}_{1} 8 \mathrm{I}_{423}$.

3 Le Populaire, June 27, 1846.

4 Almanach icarien pour 1847, pp. 135-136. 
There is no question here of declaring solidarity beyond the working class; nothing about fraternity of all men, only of all working men. The only thing which divides him from Marx and Engels a year later is the comment "that they should sign a petition to demand justice and their rights". This is, of course, a significant difference, and the failure to opt for class war, even though development of this thought would seem to demand it, provides the foundation of the thesis presented here: petition rather than proletarian revolution evolves into escape rather than revolution.

What value petition? If the Bourgeoisie is without real sympathy for the working class plight, could such moral action have any effect? Experience showed that when faced with workers whose faith in the true doctrine of the working class, communism, was unshakable, the radical bourgeoisie would join "les conservateurs". In December 1846 , such a situation arose in Niort in selection of officers of the National Guard. Cabet commented, relating to this situation:

"La Bourgeoisie ne se disait-elle donc Démocrate et Populaire qu'avec arrière-pensée et à la condition tacite que le Peuple la choisirait chef? N'invoque-t-elle l'égalité que contre l'Aristocratie, sans la tolérer pour le Peuple? Les mots Peuple et Démocratie ne sont-ils dans sa bouche ou sous sa plume que les leurres, pour mener le Peuple à lui servir d'instrument? Est-elle toujours prête à coaliser avec les Conservateurs, plutôt que de consentir à traiter le Travailleur d'égal à égal?" 1

His obvious answer to all of these questions is yes. Yet Cabet could not bring himself to draw the logical conclusions: that the bourgeoisie and proletariat possessed almost entirely contradictory interests and that their antagonism was built into the "désordre sociale" of contemporary France. In the midst of his new assessment of class relations, Cabet was still searching for signs that reconciliation of interests was possible. Indeed, he found one in the victory of the Anti-Corn Law League in England. He held it up as a symbol of the fruits to be gained from class collaboration; if only the bourgeoisie of France could see the light $!^{2}$

It is freely admitted that the transition in Cabet's attitudes on class relations was not a total reversal of his former position. Only a tendency is outlined here. In the middle of 1846 , while he was warning

${ }^{1}$ Le Populaire, December 25, 1846.

2 Ibid., February 26, 1846 and August 28, 1846. In the latter, Cabet painted the archadvocate of nineteenth century laissez-faire economics, Richard Cobden, in truly heroic colors. Clearly, we must still have reservations about the extent of Cabet's sophistication. 
the workers not to trust the bourgeoisie, he himself was corresponding with Lamartine. ${ }^{1}$ The subject concerned a loan of 30,000 francs to help convert le Populaire into a weekly. Lamartine turned him down without reservation. Although too much should not be made of this occurrence, it demonstrates that Cabet had not completely despaired of the good will of some bourgeois. The refusal, however, may have added to his negative attitude toward the bourgeoisie. He remarked in his last letter to the great poet that he would succeed in his design anyway by virtue of "an act of devotion of the People".

Cabet's changing attitude toward class relations demonstrated a more certain grasp of existing social realities and, at the same time, made his tactical position increasingly tenuous. But he had sophisticated his thought on the nature of the society of his day in another respect as well. This was his primitive discussion of capitalist concentration. He presented no iron law of capitalist development but nevertheless srticulated the opinion that the transition to communauté would be facilitated by the monopolization of the means of production into the hands of a few "gros capitalistes". The first manifestation of this idea was tucked away in one of Cabet's finest brochures, L'Owrier; ses misères actuelles, leur cause et leur remède; son futur bonbeur dans la communauté; moyens de l'établir (Paris, June 1844). Cabet, it will be remembered, was a staunch advocate of the positive role of the industrial revolution in the process of freeing man from the bondage of misery. Icaria is a technological paradise. His argument on concentration is therefore integrally connected to the multiplication of labor saving machinery.

"On dit aussi que les chemins de fer et les bateaux à vapeur étaient impossibles: mais les machines révolutionnent tout; et ces machines, qui rendent nécessaire une réorganisation sociale en augmentant la misère des ouvriers [through technological unemployment], rendent la Communauté facile en augmentant la production: il n'y aura plus qu'à décider une équitable répartition des produits.

Tout conduit et même entraîne aujourd'hui à la Communauté; tout se concentre et tend à l'unité; on voit se former d'immenses maisons de commerce (comme la Ville de Paris, Chambellon, etc.) qui tiennent la place de 40,50 , Ioo petites maisons; de grosses compagnies financières pour exploiter les chemins de fer, etc., etc.; on voit des compagnies houillières s'unir pour n'en former

${ }^{1}$ Three original drafts of letters dated August 31 , September I7, and October 1, 1846 from Cabet to Lamartine exist in the Cabet papers at the IISG. 
qu'un seul, etc., etc. ..."1

Cabet's most pointed statement of the phenomenon came a year later when, after reprinting part of an extremely incisive article in la Revue indépendante on concentration (with special reference to the impact of confection on the clothing industry) Cabet made this significant comment:

"Oui, la concentration financière, industrielle et commerciale est l'un des principaux caractères de l'époque et le grand mouvement depuis quelques années.

Et ce mouvement ne peut que s'accroître dans une progression rapide.

Et c'est lui qui amènera la Communauté; car, d'un coté, en ruinant tous les petits industriels, il rend nécessaire une grande réforme sociale; et d'un autre coté, en concentrant les ateliers, les magasins, les mines, les chemins de fer, etc., etc., il démontre les économies et la puissance de la concentration, de l'association, de l'unité, et prépare les voies de la Communauté, qui n'est autre chose que la plus vaste association et la plus complète concentration, mais dans l'intérêt de tous.

Réalisée dans l'intérêt de quelques-uns seulement en ruinant la masse, la concentration serait un fléau; mais réalisée dans l'intérêt commun sur la base de la fraternité, la concentration, qui s'appelle alors le Communisme, est le plus grand des bienfaits pour l'Humanité." 2

Cabet seemed to be saying that a sort of determinism was operating in the evolution of capitalism. He never made this the core of his argument for the victory of communism, however. The eradication of a psychological factor, égoisme, remained the central prerequisite. Nevertheless, the historian cannot ignore the fact that the man whose lack of a scientific bearing and total naïvete about the realities of his society have been considered platitudes was actually cognizant of a concrete relationship between economic development and future social organization.

On October 31, I846 Cabet repeated: "La richesse, non-seulement de la France, mais encore de l'Europe tout entière [the direct reference was to the great financial houses of Baring and Rothschild], finira par se concentrer aux mains de quelques individus, les gros capitalistes". ${ }^{3}$ Such an estimate now had more meaning for Cabet since his view of class relationships saw little hope for reconciliation of interests. In

1 Cabet, L'Ouvrier, pp. 40-4I.

2 Le Populaire, July 13, 1845.

Ibid., October 31,1846 . 
this new framework his idea of concentration became an argument against overly concerning himself about bourgeois support; or perhaps it had been a factor in reducing this concern. Whichever the case, it is clear that together, Cabet's willingness to give up the quest for bourgeois collaboration, the emphasis on proletarian solidarity, and the idea of the concentration of capital, all bring us the picture of a new Cabet. In every way he appears more realistic in his assessment of the social scene. Sobered by bourgeois rejection of his doctrine, he seems to realize that communism can have meaning for the working class alone. Sophisticated by the daily study of capitalist society, he has found within it an economic basis for its own transformation. Beyond this, he said that the problem was international: as has been shown, he even spoke of Europe-wide solidarity of the working class and of concentration of capital on an international level.

Thus illuminated, what should be his tactics? Should he continue to try to build working class support while capitalism devours itself, waiting until the bourgeoisie is small enough to be eased from economic and political power? This would imply continued propaganda on the same old pacifistic and legalistic basis with the aim of creating a great international communist mass movement. But one thing must have bothered him: even assuming that the bourgeoisie becomes greatly diminished, it would still have the wherewithal, because of its great financial power and political dominance, to put up a solid wall of opposition against any movement, no matter how numerically strong, which would not resort to violence. Would mere words batter down this wall?

We have already mentioned that Cabet was involved in a polemic with the Fourierists from late 1845 and throughout 1846 . In the course of this debate, his adversaries repeated with telling force that all the words in the world, indeed even the actual democratic installation of a communist regime, would not be sufficient to pry the bourgeoisie loose from its property. (This is precisely why the pacific Fourierists felt that some rights of private possession had to be maintained within the phalanstère.) To try to do this would inevitably bring it to arms. ${ }^{1}$ The weakness of Cabet's counter-arguments to such assertions indicates that perhaps he might have half-believed them.

If Cabet was in fact convinced that the bourgeoisie would fight, and, as we have seen, much of his experience in 1845 and 1846 seemed to point to this, then his logical stand would appear to have consisted in orienting his movement towards the prospect of violence. Icarian communism would have to become revolutionary.

1 Good examples of this argument may be found in la Démocratie pacifique, November 2, 1845 and December 6, 1846. 
Revolution! Etienne Cabet? Had he not said "Si je tenais une révolution dans ma main, je la tiendrais fermée, quand même je devrais mourir en exil?" ${ }^{1}$ Certainly Cabet is remembered, and rightly so, primarily for his conviction that all opponents of communism must be persuaded of their error. Nor does the present writer entertain any idea of trying to present a very greatly altered view of the assertion of Prudhommeaux and others that Cabet never swerved from his opposition to revolution. But the problem is somewhat more complex than it has usually been presented.

In the first place, it should be recalled that Icaria itself was the result of a revolution after which "le bon Icar" was given short-term dictatorial powers to lay the foundations for the transition to communism. ${ }^{2}$ Secondly, Cabet had been an ardent revolutionary before and during the Revolution of 1830 . He was a member of the Vente suprême of the Charbonnerie and probably wrote the famous description of the trial and execution of the four sergeants of La Rochelle. ${ }^{3}$ In a manuscript dating from I 827, Cabet presents an "Exposé d'une révolution nécessaire dans le gouvernement de la France" in which he simply calls for the youth of "la classe moyenne" to rise in arms against the Restoration. On the conquest of power, a short dictatorship would be established with none other than Louis-Philippe, duc d'Orléans, at the helm.4 During the revolution of 1830 , he did not fight - because, he says, of his bad eyesight - but was a member of the revolutionary commission municipale of the eleventh arrondissement, quartier du Luxembourg; he proudly proclaimed himself a "man of July". ${ }^{5}$ Immediately following the revolution, of course, Cabet was no longer a revolutionary: he received the post of Procureur-général of Corsica. But he quickly realized that the July Revolution bote no "democratic" fruits, managed to get himself dismissed from this isolated post, and successfully ran for deputy from his home departement, the Côte d'Or. In the Chamber, he was regarded as the most radical voice of democracy. Whether or not he actively promoted revolution during the stormy years from 1832 to 1834 is open to question. He was the secretary-general of the non-

1 Cabet, Voyage en Icarie, 3 rd ed., p. 565.

2 Ibid., pp. 336-347.

3 This notice, the "Mort héroique de Bories, Goubin, Raoulx et Pommer; récit fait, raconté et distribué le lendemain de l'exécution", was printed in the Almanach populaire de la France (Paris: Pagnerre, I 848). The editor stated: "Cet écrit autographe ne portait pas, on le pense bien, de signature, mais parmi les carbonari on savait qu'il etait de M. Cabet."

4 This valuable manuscript, already cited, is in the Cabet collection at the IISG. The most pertinent pages are 32-47 and 64-68.

5 Cabet, Poursuites du Gouvernement contre M. Cabet, zème partie(Paris, I 834), pp. I I-1 2. 
violent Association libre pour l'Education du Peuple during its most successful year. But evidence exists to the effect that this organization was infiltrated, perhaps dominated, by the revolutionary Société des Droits de l'Homme in the second half of $1833 .{ }^{1}$ While never joining the latter, Cabet seems to have drifted with the tide; but we know that when M. Albert came from Lyon to Paris for instructions two months before the days of April I 834, Cabet advised against violence. ${ }^{2}$ So did Buonarroti and a host of members of the Droits de l'Homme itself, however.

What was Cabet's attitude toward revolution during the years with which we are concerned? Arnold Ruge doubted the sincerity of his pacificism. Writing in 1846 , he remarked, "Es versteht sich, daß die Legalität Cabets sich nur auf die factische Haltung, nicht die Ansicht bezieht." 3 Engels himself held the same opinion (perhaps he was Ruge's source) in his exposition of French Socialism in the Nen Moral World (November 4, 1 843): "Even the Icarians, though they declare in their publications that they abhor physical revolution and secret societies, even they are associated in this manner and would gladly seize upon any opportunity to establish a republic by force." 4 These opinions are not sustained by the other important Germans who wrote on the French communism, Grün and von Stein, ${ }^{5}$ nor is this point of view presented by any of the French and English analysts who studied Cabet. Was there any foundation to the comments by Ruge and Engels? Only two documents cloud an otherwise clear picture of opposition to revolutionary violence. One is a "Note à X" in which our anti-revolutionary proposed that $X$ head up "un gouvernement occulte, une Dictature secrète" prepared to take power should a revolution break out. ${ }^{6}$ The failure of the action of May I 2 ( 1839 )

1 Archives Nationales, F 176674 dos. Association libre pour l'Education du Peuple and BBI 81338 .

2 Louis Blanc, Histoire de dix ans, I 3 th ed., (Paris, I883), vol. IV, Pp. 24 I-242.

'Ruge, "Cabet und der Humanismus", in Zwei Jahre in Paris, vol. I, p. 71 (Leipzig, 1846).

4 Engels, "Progress of Social Reform on the Continent", in MEGA, Erste Abt., Band II, p. 440.

${ }^{5}$ Karl Grün, Die soziale Bewegung in Frankreich und Belgien (Darmstadt, 1845), pp. $329 \mathrm{ff}$; Lorenz von Stein, Geschichte der Socialen Bewegung in Frankreich (Leipzig, I850), vol. II, pp. $334 \mathrm{ff}$.

- This manuscript, in Cabet's hand, is perhaps the most important document in the Archief Cabet at the IISG. Unfortunately, we are unable to date it precisely. The date appearing at the end is mercredi, 22 août. Internal evidence shows that it was written sometime after " 12 mai" (undoubtedly referring to Blanqui's abortive émeute) but during the July Monarchy. Unhappily, no Wednesday fell on August 22 between 1839 and 1848 (though this was the case in both 1838 and 1849). One must conclude that Cabet made a mistake either as to the day of the week or as to the date. The most likely year seems to be 1839 since he would have missed either day of the week or date by a single day in that 
demonstrated the need for such an organized subterranean unit. Cabet proposed that the top levels of this shadow government ought to meet twice per week; following the Buonarrotist-Blanquist formula, he recommends that the lower echelons of the organization be ignorant of the names of the high leadership. The upper levels of the structure should consist of fourteen committees of three to five members each of which would correspond to the departments of the present government. Cabet makes it quite clear that this organization should not promote revolution but rather be prepared to take over "if a revolution should occur". Nevertheless, this document at least complicates Cabet's position on revolution even if it does not tag him as a secret revolutionary in the post-exile period of his activity.

Now it is manifest that in all of his published writings during the 1840 's, "on ne trouverait pas une ligne de Cabet, pas un article du Populaire que l'on puisse invoquer comme un appel à la force déstructrice ou comme encouragement à la basse démagogie."1 But one incident, recorded by the Procureur-général of Lyon, throws doubt on the absolute sincerity of Cabet on this score and lends some support to Engels's contemporaneous comment. After his triumph at Toulouse, Cabet visited Lyon in September 1843 in order to confer with his party there. The question of his anti-violence was raised; several dissidents reproached him for working for the regeneration of society "par moyens trop lents. Ils lui ont déclaré qu'ils ne pouvaient attendre indéfiniment les avantages qu'il leur promettait." Then Piou, swearing to the veracity of his information, presented this revelation:

“Le Sieur Cabet a répondu que jusqu'ici il avait pensé que la société pouvait être régénérée par la seule influence du raisonnement et de la publicité, mais qu'il reconnaissait aujourd'hui que l'emploi de la force était nécessaire pour accomplir cette grande cuvre. Il a ajouté qu'on ne devait rien tenter, par cette voie, du vivant du Roi, mais que la levée des boucliers se ferait avec avantage à l'instant de sa mort."

Piou later noted that this apparent shift in Cabet's position " $a$ eu pour effet de lui rallier tout le parti communiste, qui a presque totalement absorbé les autres associations secrètes". The communists of Lyon

year; furthermore, the repeated mention of May 12 points to this conclusion as does the general tenor of the document.

1 Prudhommeaux, op. cit., p. 200.

2 Procureur général de Lyon to the Garde des Sceaux, October 2, I 843, Archives Nationales, $\mathrm{BB} 18$ I4Is. 
had been instructed by Cabet "[ne] pas prendre au sérieux la politique pacifique de son journal". 1

How should the historian assess this allegation? In the first place, a thorough investigation on the Icarian movement at Lyon ${ }^{2}$ has produced absolutely no corroboration of this indictment. Sébastien Commissaire, an ardent Icarian at this time, makes no mention of such a statement by Cabet even though he remembered that at this point (he thought it was in 1844) "Une scission se produisit à Lyon parmi les partisans du communisme icarien: les uns voulaient établir ce nouvel état par la violence; les autres ainsi que leur chef Cabet attendaient tout de la propagande pacifique" and also that this situation brought Cabet to Lyon. ${ }^{3}$ The report of the Procureur-général leaked out and Cabet denied it. Still, the positiveness of Piou's remarks is troubling. Beyond this, we know that a secret organization called the bibliotheques, made up of Icarian sympathizers, was prosecuted as a secret society the following year. ${ }^{4}$ Commissaire himself points out that Icarian meetings always had a real and an apparent aspect: in actuality, the meetings were highly political and regular, but "il était convenu que toutes les fois que la police se présenterait, on jouerait aux jeux innocents."5 It appears, therefore, that a definite conclusion with regard to this situation is impossible to draw; nevertheless, it provides us with another shred of evidence that Cabet's alleged total disdain of revolution must be viewed with some suspicion.

The most correct judgement of Cabet's attitude toward violence and revolution appears to be this: although for purposes of safety he rendered the appearance of being entirely opposed to revolution in any form, he could conceive of revolution as a means of social change if it would be one of the entire nation (which for him meant the vast majority of useful citizens of the nation) against a corrupt and selfseeking clique controlling the government; such had been the case at the advent of the revolutions of 1789 and 1830 . What he really opposed was the formation of secret societies like the Seasons or the Charbonnerie réformée. That he significantly reduced the propensity of workers to involve themselves in the latter is a fact of no mean importance in the history of the maturation of the French working class. But, though he might view revolution of the sort described above with some favor, he could not stomach the specter of class war. Even though he seemed willing to push the bourgeoisie into the

1 Ibid., October 22, 1843.

2 This includes a study of the relevant documents at the Bibliothèque municipale de Lyon.

${ }^{3}$ Commissaire, Mémoires et souvenirs (Paris and Lyon, 1888), vol. I, p. 98.

4 Cabet, Les masques arrachés, pp. 4I-44; Archives Nationales, BB 18 I423.

5 Commissaire, op. cit., p. 98. 
cadre of oisifs, even though he recognized the unwillingness of the bourgeoisie to promote the true working class doctrine (i.e., communism), even though he realized that elements within the bourgeoisie had spirited away the revolutions of 1789 and 1830 , even though he understood the deep class antagonism which rent the society of his day, Cabet could not bear to sanction the tragic spectacle of class battling class. In a moment we shall observe how he reacted to the June Days.

The purpose of the foregoing comments has been to demonstrate that the image of Cabet the timid anti-revolutionary is somewhat overdrawn. Given this background, it is legitimate to hypothesize that he very probably considered the option of encouraging working class preparation for revolution during the period in which he redefined his attitude toward class relationships. Secret societies would be out of the question, but he had already developed an open movement of significant proportions, and to imply that it should think in terms of revolution as a long range goal would not have been impossible. The July government, while it could successfully prosecute secret societies which detailed the plans of revolutionary upheaval, did not have the means to destroy an idea. After all, both the Babouvist la Fraternité de 1845 and la Réforme itself were implicitly revolutionary and still managed to avoid the tentacles of the law. Cabet could have maintained the same loose organization of his movement - with le Populaire as the unifying center - and simply changed the tone of his pronouncements or perhaps secretly communicated the new direction. But the option of revolutionism, because it meant sanctioning overt class conflict, proved to be repugnant to him; the only alternative which appeared viable, therefore, was escape.

Events during the months of late I 846 and early I 847 pushed him toward the latter option. The bad harvest of 1846 created the bases for a "crise de l'ancien type", 1 and the ensuing high price of bread and unemployment induced an attitude of desperation among large segments of the French working class. Icarians were not unaffected; the situation increased the inclination of some of them to seek revolutionary solutions.

In late 1846 , communism was expanding apace. The major question, however, is whether Icarianism was expanding as rapidly as the outwardly revolutionary communist elements. One situation indicates that the answer to this should be negative. At Tours, a sizable faction of Icarians were drawn into an association allegedly under the inspi-

1 See Ernest Labrousse, "Panoramas de la crise", in: Aspects de la crise et de la dépression d'économie française au milieu au XIXe siècle, 1846-189 I (La Roche-sur-Yon, I956). 
ration of the irrepressible Auguste Blanqui, currently at the local hospital recovering from the brutal hardships of his imprisonment at Mont-Saint-Michel. ${ }^{1}$ This development disturbed Cabet highly; he wrote a brochure disclaiming his renegade followers. ${ }^{2} \mathrm{~A}$ letter from Cabet's agent at Tours, the doctor Louis Desmoulins, written on November 26, 1846, points up the problem which pacific Icarianism was facing. There was a feeling among many at Tours that Cabet wanted to "faire définitivement chavirer la barque révolutionnaire". He goes on to say that the dissidents believe that Cabet made a great error in going ahead with the publication of the Vrai Christianisme because it had the effect of re-emphasizing his penchant for moral appeal and pacifism. The following words must have struck Cabet squarely between the eyes given the state of his thought at this time:

"Vous me demandez pourquoi contre vous, il peut y avoir un complot? Les raisons en sont fort simples: vous êtes le seul obstacle qui empêche le parti communiste de devenir à l'instant terriblement révolutionnaire ...., et la révolution est une chose aussi charmante qu'elle est facile à faire ... en imagination. Or, beaucoup déjà des plus remuans parmi nous sont pour les moyens insurrectionnels tandis qu'aujourd'hui ils vous paraissent tout à fait inopportuns. Donc voilà bien un motif de comploter contre votre influence."3

Thus the Tours situation set the difficulty in bold relief: if he should continue to follow the proposition that the development of a nonviolent mass movement was his most effective tactical program, would he not face the possibility of losing much of his large following to the more revolutionary advocates of communism? On the other hand, even if he did turn toward a revolutionary path, he would destroy the uniqueness of his position and blacken his image as the generous bonbomme, the fatherly friend of all mankind. And beyond this, there was the very practical consideration of the probable outcome of any revolution in the near future. It was evident that a switch to revolutionism during or shortly after the difficult winter

1 After a minor manifestation protesting the price of bread, several Icarians (and others) were incarcerated and charged with conspiracy. The principal government witness, Houdin, drew Blanqui's name into the trial and charged that he had organized them as a secret society. See the Gazette des tribunaux, April 3, I 847 and April 29, I 847 and Anon., Les communistes de Tours; persécutions de police à Blois (I 847) (Bib. Nat. Lb5I 4338). The pertinent archival sources are Archives Nationales, $\mathrm{BB}_{21}$ 5028 and Archives départementales de Loir-et-Cher, 3 UI 42 (Audiences correctionelles de 26, 27, 28, 29 avtil 1847).

${ }^{2}$ Cabet, Le voile soulevé sur le procès communiste à Tours et Blois (Paris, 1847 ).

2 Desmoulins to Cabet, November 26, 1846 , Papiers Cabet, BHVP. 
of $1846-1847$ would have indicated but one thing to his followers: immediate violent action was in order. Given the disorganized state of the working class, he felt this would have been disasterous. In the first part of his Réalisation d'Icarie, published shortly after his proposal to emigrate, Cabet pointed out that even should a revolution succeed, "les résultats ne seraient pas pour le peuple, mais pour la bourgeoisie" due to the fact that "le peuple n'est pas assez éclairé pour empêcher les ambitieux d'escamoter sa victoire.”

The evolution of Cabet's thought since the rift with la Reforme had forced this question to the forefront: if a political solution to the problem of the degradation of the working class remained the aim, was it possible to foresake the ideal of class collaboration and at the same time retain the posture against violence? It seems abundantly evident that Cabet, impressed with recent experience, especially the frightening development at Tours in which Icarians were drawing their own conclusions in favor of violence, found himself confronted with a negative answer. To remain in France would have demanded that he promote proletarian revolution, at least as a long range goal. Cabet could not overcome his moral and purely personal reservations to such a solution, nor could he put the vision of a revolution escamotée by the bourgeoisie out of his mind. Hence, what else could he do but opt for escape from the entire dilemma?

Two and one-half months after the call to emigrate had been issued, Cabet summed up the situation in reply to the assertion by l'Emancipation of Toulouse that the bourgeoisie should lead the fight for "democratic progress":

"Hé bien! ne voilà-t-il pas un journal bourgeois-radical ou républicain qui fait un bel éloge des chefs de la bourgeoisie! Et le Peuple n'a-t-il pas raison d'être communiste et de vouloir fonder avec nous Icarie, lorsque l'égoïsme bourgeois l'a si long-temps exploité et trompé?"1

The bourgeoisie is our enemy but we cannot go to war with it; therefore let us avoid the conflict by leaving the scene. Such are the terms in which Cabet attempted to solve his dilemma. An exclusively working class mass movement directed toward revolution against the existing order was the other alternative - one, as we have seen, not without reasonable bases in his changing ideas on class relations. Several of his followers in France opted for this alternative both

1 Le Populaire, July 25, 1847. 
before and after the decision to emigrate. ${ }^{1}$ Of greater historical significance was the ease with which the bulk of the German communist exiles in London, after passing through a phase of real sympathy for Cabet, came under the influence of Marx and Engels. Although Schapper, Moll, Bauer, and their friends were never devoted Icarians, the discussions of 1845 , recorded in their Protokollbuch, demonstrated that Cabet was their favorite communist theoretician and that they were especially impressed by his opinions on the need for a mass movement and his denunciation of conspiratorial organizations. ${ }^{2}$ Their evolution is a quite substantial demonstration of how short the bridge from Cabet to Marx really was in I846-I 847 . But for Cabet himself, the bridge appeared long and shaky. Engels visited him in August 1846 and, despite his warm reception by the venerable chef des communistes icariens ("Der alte Knabe war recht kordial ..."), he was apparently unable to develop Cabet's interest in any sort of association with the Communist Correspondence Committee in Brussels. ${ }^{3}$ Thus, while some adepts and sympathizers of Icarianism were moving toward a realistic attitude with regard to the means by which to solve the problem of working class degradation and exploitation in the society of their day, their leader let his past history, his partially bourgeois mentality, and his deep urge to remain the leader of a distinct school lead him to the impotent "tactic" of emigration.

We have argued that this decision to escape derived from Cabet's recently developed feeling that the interests of the bourgeoisie and proletariat were almost hopelessly at odds and that all action in Europe short of overt class warfare would be fruitless. This was not the reason which Cabet gave in justifying himself. To do so would

\footnotetext{
1 We have already discussed the Tours development of $1846-1847$. At Toulouse, a similar problem had arisen already in 1845 . Perpignan, Cabet's correspondant there, wrote him that the movement was fading in face of competition from the more revolutionary communists (letter of July ro referring to the recent pubiication of Cabet's brochure, Cataclysme social (June I 845), Papiers Cabet, BHVP. After the emigration announcement, a sizable group at Nantes, one of the principal Icarian strongholds in France, rejected the plan to emigrate on the grounds that the working class needed to stand united in its homeland and prepare to resist impediments placed in the path of progress. J. J. Razuret, an extremely influential Icarian chef d'atelier of Lyon, protested against the emigration in a similar vein and felt that a "revolution is near" (le Populaire, October 22, I847).

${ }^{2}$ Nettlau, op, cit., passim.

3 Such was not the case with one of Cabet's intimate associates, Hermann Ewerbeck, however. It is clear from Engels' correspondence that he was much closer to Marx and Engels (in spite of his disapproval of their "hardheartedness" with regard to the Weitling problem) than Cabet suspected. For all this, see MEGA, Dritte Abt., Band I, pp. 26-37. On Ewerbeck, see Edmund Silberner, "La correspondance Moses Hess-Louis Krolikowski", in: Annali dell' Istituto Giangiacomo Feltrinelli, 1960, p. 608, n. 1 3.
} 
have meant that he relinquish the one tenet which distinguished his "school" from the other communists. He said that persecution by the government threatened to destroy communism in France; it could only be saved by running away. Prudhommeaux and Angrand accept this explanation, the latter pointing to Duchâtel's strongly worded letter of March 30, I847 to the Minister of Justice which shows his will to crush le Populaire at all costs when it became a weekly published at Rouen. ${ }^{1}$ But the legal measures which the government promoted against the newspaper in April 1847 were of no avail. More importantly, Cabet stated as late as April I I , I 847 that persecution only strengthened the movement: there exists "un vaste système de persécutions de la part des prêtres, des privilégiés et du pouvoir; mais n'ayons pas peur! La persécution doublera notre énergie, accélérera nos progrès et rendra plus prompt et plus certain le triomphe de nos doctrines." And indeed, such seemed to be the case with most of the incidents of persecution which Cabet lists supposedly to support the emigration decision as they appeared in the issues of le Populaire of May and June I 847 .

\section{IV}

The Revolution of 1848 in France demonstrated in brutal fact the half-articulated opinion of Cabet that class collaboration was an impossible dream. Union ouvrière thereafter was the keynote of any theory in tune with reality. The First International provided the concrete manifestation of this new level of thought: neither Proudhon nor Marx, despite the extent of their disagreement in other respects, doubted for a moment that la question ouvrière had to be resolved by the workers themselves.

The June Days stand as the great watershed between collaborationism and exclusivism. ${ }^{3}$ It is worthwhile to set down Cabet's views of the situation. In April and May, Cabet, in spite of his moderate stand with regard to the revolution, had been beaten from pillar to post by charges, backed up by acts of violence against him, that he, Blanqui, and the rest of the communists were planning to turn the revolution

1 Archives Nationales, BBI8 145 I.

2 Le Populaire, April II, 1847.

${ }^{3}$ Whatever the real nature of the warfare of June (Rémi Gossez argues convincingly that Marx's bourgeois-proletarian confrontation was an oversimplification in "Diversités des antagonismes sociaux vers le milieu du XIXe siècle", in: Revue Économique, VII (1956), pp. 439-457), in the mind of the French working class, the horrors of these days and the recriminations which followed made the breach between the bourgeoisie and the proletariat seem irreparable. 
into a blood-bath from which a communist dictatorship would emerge. By June, he had revived the decision to emigrate and, in fact, was probably in the Midi making arrangements for the next départ when the insurrection broke out on the twenty-third. ${ }^{1}$ But Cabet understood the significance of the uprising. Class antagonism is fully recognized and he predicts that without amnesty, "la guerre sociale" will become endemic in France. Still, note his phraseology: "S $i$ vous restez dans la voie des haines et des vengeances, ce seront les haines et les vengeances partout, s'irritant et grandissant chaque jour. ... Ne sera-ce pas un état perpétuel de la guerre?"2 Somehow he yet feels that class hatred can be buried by an act of will, and the general aim of the brochure is to plead for amnesty lest class war become the dominant social reality. Cabet could not disabuse himself of the notion that class antagonism could only lead to degenerating anarchy. Nevertheless, he does not misread the history of the Revolution of i 848 . The June Days were the result of the failure of the bourgeois-dominated government to develop a strong policy of social amelioration. “'C'est lui, le Gouvernement, c'est le National, c'est la Réforme, ce sont surtout Ledru-Rollin et Lamartine, qui ont tout perdu." 3

But did the responsibility for the unhappy evolution of 1848 rest fully in the hands of two-faced bourgeois democrats? The glow of unity which characterized the month of March, the working class generosity and noncombativeness, the "wait and see" attitude, drew a great deal from Icarian doctrines of legalism, pacifism, and courage civil. The strongest statement of this opinion was made by Pierre Leroux in La Grive de Samarez (although he felt that this influence was beneficent): ". . . qui, en 48 , a fait plus de bien que Cabet?

Est-ce que la révolution de 48 a ressemblé à celle de 93 , ou même de 89 ?

1 Cabet was arrested, however, on the basis of allegations to the contrary. A report from the Prefect of Police to the Minister of the Interior, drawn from a note from the subprefect at Bar-sur-Seine, stated that a veterinarian named Martin testified that he rode with Cabet in a diligence headed for Paris on June 22. Cabet was alleged to have told him that he was "impatiently awaited" in Paris. Furthermore, one Mme Loisel claimed that she saw Cabet during the insurrection in the rue des Gravilliers (Quartier Feydeau) telling several workers gathered around him that "s'ils ne réussissent pas aujourd'hui, ils réussiraient plus tard". This report is located among the documents relating to the investigations of the insurrections of May 15 and June 23-26 in the Archives de la Ministère de la Guerre (dos. 3753). Similar visions of Cabet were reported on April i6 and May i5; the tribunal believed Cabet's assertion that he was in Marseille during the insurrection and rendered a decision of non-lieu.

${ }^{2}$ Cabet, Insurrection du 23 juin avec ses causes, son caractère et ses suites, expliquée par la marche et les fautes de la Révolution du 24 février (Paris, 1858), pp. 17-I 8 (my italics). 3 Ibid., p. 25. 
A qui le doit-on?

A Etienne Cabet plus qu'à tout autre.

C'est nous; et, au début, c'est Cabet principalement, parce qu'il était dans un rapport intime avec les classes ouvrières. C'est Cabet qui, ayant fait luire aux yeux des Masses l'idée consolante et pacificatrice d'une société fraternelle, leur rendit odieuse la seule idée d'une révolution où l'on emploierait la guillotine et la lanterne; j'ajoute le sabre et le fusil!"' 1

Leroux lauded Cabet for saving the Revolution from turning to carnage, for instilling in the workers a sense of probity and respect for the ideal of the brotherhood of all men. But did he spare the revolution from the agony of June when the workers, reaching the limits of this probity, fought an essentially defensive battle in disorganized desperation, a battle which they had little chance of winning? If we accept Leroux's assessment of the extent of Cabet's influence, what the balm of his rhetoric really did was to contribute to the probability that the revolution would indeed be conjured away by the bourgeoisie. When the revolution broke out, a large number of those under his influence were still dreaming of the never-never land across the seas, and those who involved themselves in the developing revolution, like the Icarian leader at Reims, Eugène Butot, were working among their fellow laborers to keep them from seeking revenge against their exploiters. ${ }^{2}$ Cabet the "endormeur" bade the people to rest when the situation demanded a revolutionary readiness on the part of the working class. Although the wealth of the bourgeoisie and the sheer weight of rural France might still have precluded any meaningful working class gains, Cabet's inability to surmount his reservations about the use of force - despite developments in his own thinking which pointed in this direction - both before and at the

${ }^{1}$ Leroux, La Grève de Samarez (Paris, 1864), vol. II, pp. 377-378.

2 Butot was a member of the provisional municipal government at Reims and had been instrumental in preventing further acts of violence after the attack on the spinning factory of Thomas Croutelle on February 25. See Gustave Laurent, "La Révolution de 1848", in: Le Département de la Marne et la Révolution de r848 (Châlons-sur-Marne: Archives de la Marne, I948), p. 48. The history of Butot during the ascendant period of the Revolution illustrates the poverty of the Icarian position. Because of his ardor for pacifism, he was regarded by his bourgeois associates as harmless, and his articulation of working class desires was in large measure ignored (though some social progress was made in Reims in 1848). At the same time he had enough prestige to hold the hungry and bitter elements among the workers in line. His power faded during April as advocates of stronger measures, under the leadership of the worker-poet, Gonzalle, emerged. For an idea of Butot's views, see his electoral confession of faith, Deux mots aux citoyens Électeurs, contained in the collection of 1848 materials of Lacatte-Joltrois, Abrégé historique, vol. iv, ms. I686, Bibliothèque municipale de Reims. 
inception of the revolution made its reactionary dénouement all the more likely.

Georges Duveau has left us this hypothetical picture of the evolution of the Icarian mind in 1848 :

"Donc, en quarante-huit, notre ébéniste ne marchande pas sa confiance dans le Gouvernement Provisoire, car il est convaincu qu'en un tournemain Lamartine, Marrast, Louis Blanc et Marie vont édifier une Icarie. Mais quand il voit ses camarades pousser nonchalamment quelques brouettes sur le Champs-de-Mars, sa rêverie prend un tour plus désabusé. Il croit, non sans raison, à des machinations hostiles, ténébreuses, au sein du gouvernement; il se dit que la manière forte serait sans doute préférable à l'abandon ingénu dont il a fait preuve en février. Il relit Buonarroti, et ainsi se prépare Juin."1

June was too late, however. The willingness to use the manière forte among Icarians was necessary before the revolution and certainly from its inception if concrete benefits for the workers were to result. Etienne Cabet, perhaps more than any other man, had been in a position to create the strenth of conviction, based on a readiness to fight, to force a positive solution to la question ouvrière in France. But instead, he had chosen first to flee and then, when the revolution occurred, to remain firmly in the mold of pacifism.

Is there any justification for this seeming failure on Cabet's part? Perhaps. More recent history has taught us to be wary of the belief that there does not exist an intimate connection between means and end: can the good and the perfect issue from violence and destruction? Must not the means place an indelible imprint on the end? Cabet never really explored this question himself, but one of his adherents, J. Moreau, a Parisian worker, was aware of the problem; his simple language traverses a century of disappointment with the fruits of revolutionary violence and bears the essence of the utopian message. His words appeared in le Populaire of October 31, 1847 :

"... le communisme convaincu a horreur de la destruction, et c'est une contradiction étrange que de vouloir établir le bien à l'aide du mal. ... [II] est toujours dangereux d'employer la violence pour faire triompher la raison, parce qu'un homme battu n'est pas un homme convaincu. J'ai un horreur du sang; je crois que l'homme a pour mission de construire, et non de détruire."

1 Duveau, op. cit., p. 232. 
He therefore would emigrate with Cabet. But while this may have been an intelligent and moving justification of Cabet's decision, it still begged the question. When pacific propaganda reached a dead end and when escape was blocked by the absence of viable avenues, men had no choice but to reread Buonarroti and to be satisfied if something less than the good and the perfect - or, as Moreau would haveit, reason - resulted. 